\section{B A Institute of \\ YK Business Administration \\ TK \\ Karachi \\ Leadership and Ideas for Tomorrow}

Business Review

Volume 16 Issue 2 July-December 2021

\title{
Impact of CEO overconfidence on corporate financing decision with mediating role of risk perception
}

\author{
Amina Batool \\ International Islamic University Islamabad, Pakistan \\ Tahira Awan \\ International Islamic University Islamabad, Pakistan \\ Sumayya Chughtai \\ International Islamic University Islamabad, Pakistan
}

Follow this and additional works at: https://ir.iba.edu.pk/businessreview

Part of the Business Administration, Management, and Operations Commons, Corporate Finance Commons, Operations and Supply Chain Management Commons, and the Organizational Behavior and Theory Commons

\section{(c) (1)}

This work is licensed under a Creative Commons Attribution 4.0 International License.

\section{Recommended Citation}

Batool, A., Awan, T., \& Chughtai, S. (2022). Impact of CEO overconfidence on corporate financing decision with mediating role of risk perception. Business Review, 16(2), 77-95. Retrieved from https://doi.org/ 10.54784/1990-6587.1375

This article is brought to you by iRepository for open access under the Creative Commons Attribution 4.0 License and is available at https://ir.iba.edu.pk/businessreview/vol16/iss2/5. For more information, please contact irepository@iba.edu.pk. 


\title{
Impact of CEO Overconfidence on Corporate Financing Decision with Mediating Role of Risk Perception
}

\author{
Amina Batool - Tahira Awan - Sumayya \\ Chughtai
}

\begin{abstract}
The purpose of this paper is to investigate the impact of managerial (Chief Executive Officer) overconfidence on corporate financing decision with the mediating role of risk perception. This study indicates that psychological biases affect the risk perception and ultimately financing decision of top management of an organization. The research design is causal and primary data has been used to test the proposed relationship. Among all the companies listed in the Pakistan Stock Exchange, researchers have selected top executives of 200 companies as a sample. E-Questionnaire has been used to collect the required data through LinkedIn and other mailing sources. Researcher has done a linear regression to find the relationship between independent variable overconfidence and dependent variable that is leverage. Baron and Kennys four-step mediation has been used to test the mediation effect of risk perception. Results of this study conclude that there is a significant positive relationship between overconfidence of CEO and leverage while there is a significant negative relationship between CEO overconfidence and risk perception. However, there is an insignificant result for the mediating role of risk perception between CEO overconfidence and leverage. Extensive research work is available on basic topic of how dividend policy and capital structure affect corporate performance; however, we found insufficient literature on psychological forces (behavioural biases) for financial decision making. The gap is covered by this study through explaining the impact of behavioural biases on corporate financial decisions which further distresses corporate performance. The results are significant for company top management, regulators and policy makers. This study as an empirical evidence is also helpful for researchers, academicians, and practitioners to understand and
\end{abstract}

Amina Batool

International Islamic University, Islamabad

E-mail: amnaabid5@gmail.com

Tahira Awan

International Islamic University, Islamabad

Sumayya Chughtai

International Islamic University, Islamabad

(C)Batool, A., Awan, T. and Chugtai, S. 2022 
implement the notions coined by behavioural finance, regarding the effects of behavioural biases on corporate financial decisions that ultimately affects the corporate performance. The results are in line with previous studies on emerging economies.

Keywords CEO overconfidence, risk perception, corporate financing decision, Leverage.

\section{Introduction}

Capital structure decision is an important aspect of finance. In corporate finance, various theories such as Agency theory by Jensen and Meckling (1976), Trade-off Theory by Miller (1977) and Pecking Order Theory by Myers and Majluf (1984) form the basis for corporate financing decisions. Not only conventional theories but behavioural theories are also driving the corporate financial decisions and little work has been done on these theories in Pakistan. It is argued that human behaviour at the top management level, i.e. CEO, influences capital structure, therefore, the dominant view is that the behavioural aspect is involved in corporate financing decision (Barros and Di Miceli da Silveira 2007).

According to the psychological studies, people are not completely rational which means that the leaders of the companies may also behave irrationally (Ting et al 2016). Psychology explains that human beings including experts are also prone to the biased behaviour. They show overconfidence in many aspects and studies revealed that as compared to ordinary people, managers are more likely to show overconfident behaviour. Hilary and Hsu (2011) claimed that overconfidence is a common type of cognitive bias and this is confirmed by the research work of Brick et al (2006) who state that overconfidence is a misinterpretation of the results and wrong beliefs. It is basically an underestimation about the variance of a project and further explains that in managerial overconfidence, CEOs overestimate their ability to choose the best probability regarding the success of projects and about all other corporate decisions. Boubaker and Mezhoud (2011) said that the psychological behaviour and decision makings of human beings are not rational, but their preferences and beliefs always influence their decisions.

Upper echelon theory states that the managerial personal characteristics are best in assessing the productivity, planned choices and better outcomes for an organization (Hambrick and Mason 1984). Considering behavioural factors, cognitive theory illustrates that cognitive learning of a person depends on three factors: behavioural, personal and environmental. These factors play a vital role while taking decisions. It involves heuristics and biases that will ultimately affect the individual behaviour which may lead towards irrational decisions (Baron and Kenny 1986). As per Kahneman and Riepe (1998) prospect theory, people usually evaluate gains and losses in two different manners and mostly take a decision on the basis of the perceived gains instead of perceived loss. This theory discusses the illogical behaviours and describes the way people choose between probabilistic alternatives that involve risk.

The risk is another important consideration in making financing decisions. 
Risk while taking a decision is not a single trait but is a behaviour that is influenced by many of the characteristics that involve not only the decision makers, but also the situations in which managers or any person take risks. It is the combined effect of decision maker and situation. Humans mostly rely on experiments, gut feelings, instincts and intuitions when they deal with risk, which always supports our survival in a dangerous situation. Due to various opportunities and exposure to business hazards, top management has to face risk, leading them to make a decision according to the level of risk they have to bear (Epstein 1994). In different cultures, an individuals behavioural biases vary leading to different risk perceptions. In a real aspect, decision making related to risk is separated frequently from the assumption of finance about rationality. Behavioural biases are now becoming an essential part of decision making because decision makers act irrationally. Behavioural finance work on biased behaviours has been helping the managers and investors to select better options. While taking financing decisions, there is a higher probability of managers behaving irrationally because they are less able to evaluate a project risk and return unbiasedly. Risky choices of humans need to be considered because risk perception of CEO sometimes leads to loss or gain. So, this improvement has been done by illustrating new model in this research (Bernile et al 2017; Chen et al 2011; Ting et al 2016; Tomak 2013).

Financing decision and practices in an emerging economy are different from those in developed countries due to the economic condition prevailing in the emerging country. The demographic difference, the culture of management that compel them to take ineffective decisions, irrationality due to competition among firms, liquidity constraints and political biases are good examples that impact the financing decision of management (Bekaert and Harvey 2002). In another research work, it has been demonstrated that managers in emerging economy like Sri Lanka are different. The transaction cost of debt issuance, interest rate, volatility of earnings, cash flows, and the low foreign interest rate is perceived to be significantly important by the majority of CFOs. These factors have a different impact in emerging economies as compared to developed economies (Koralalage 2016). So the objective of this paper is to advance a behavioural perspective by studying the relationship between managerial overconfidence and corporate financing structure in Pakistan with the mediating role of risk perception.

This paper may make a good contribution towards human consultants for many reasons. The prior studies have concentrated on the long term financial decisions and corporate performance. However, the focus of this study is novel by exploring the impact of behavioural bias with mediating role of risk perception on corporate financial decisions. Firstly, this study empirically examines the impact of managerial overconfidence in corporate decision making for a developing country like Pakistan, as previous work has not been done here with mediating role of risk perception. Secondly, research work has used both public and private firms in Pakistan. As the study is focusing just on CEOs, sample is considered to be large as one CEO represents one company. Thirdly, the broader contribution of the paper is to show that CEOs personal bias i-e, overconfidence bias is playing a vital role in explaining the corporate nancing behaviour of $\mathrm{rm}$ they

Business Review: (2021) 16(2):77-95 
manage. This paper may direct the top management to take rational decision while making financing decisions. To the best of our knowledge, the comprehensive empirical study based on primary data in the literature of behavioural corporate finance is on developing economies.

\section{Literature review}

Study of human behaviour in the financial decision has received a lot of importance in the current era. Due to its significance, research on the behavioural aspect has been improved and considered as a basis for making corporate decisions. Kahneman and Tversky (2013) gave some recommendations about the behaviour of human beings. Their arguments are to keep track of instances of your overconfidence, to communicate realistic odds of success to your clients and to resist the natural urge to be optimistic. THey also stated stated that behavioural finance helps to understand the real reasons why leaders know more than the market, ensures the frame chosen has relevance for the client and assesses how risk-averse your client is. But psychologists believe that human beings dont act rational, which causes them to overestimate or underestimate financing decisions. Overestimation is human behavioural characteristic and is closely related to overconfidence (Wei et al 2011).

As managers are corporate strategy makers, their overconfident behaviour significantly affects corporate financing decisions and also all the other aspects of the company (Liang and Mo 2016).In psychology, overconfidence is divided into two main categories: miscalibration and positive illusion. Ben-David et al (2013) has defined these two divisions as Miscalibration is the systematic underestimation of the range of potential outcomes. Miscalibrated people are those who overestimate their ability to accurately know about something and underestimate their risk-taking behaviour. In psychology, positive illusions comprise of three behavioural biases- unrealistic optimism, better-than-average effect and illusion of control. Unrealistic optimism is a belief that future events occur in a better manner that how they are suggested. Better than average effect people evaluate themselves better than their peer. On the other hand, the illusion of control is the tendency of people to overestimate their ability to control a situation (Weinstein 1980). According to Kruger and Dunning (1999), overoptimistic people underestimate the probability that the hazard will happen and affect them badly but they overestimate their belief that their future will be bright and outcomes will be better. Optimistic people normally give higher credit to good outcomes and lower to the bad results (Heaton 2005).

Ullah et al (2017) argued that overconfident people misjudge their expertise and knowledge on the basis of limited aspects. They proposed the concept of overconfidence on the basis of the probabilistic mental model theory proposed by Gigerenzer et al (1991), which states that people take an overconfident decision on the basis of probabilities and difficulties may arise in such type of decision making. In this situation, people think that their expertise and knowledge are complete and their decision will reap success. They underestimate risk associated with the outcome. They found the positive significant effect of the bi- 
ased behaviour of managers towards investment. Overconfident behaviour would lead to emotional behaviour that resulted in overconfident financing decisions. Liang and Mo (2016) research results revealed that the biased behaviour of managers has a positive impact on the $R \& D$ investment. If the investment was subject to financing constraints, then managerial overconfidence effect would be more prominent. Financing constraints have strengthened the relationship between managerial overconfidence and investment. Thats because the overconfident managers underestimated the risk associated with the financing through debt and overestimated the returns. Such misperception about the debt financing leads to higher debt level for firm.

Heaton (2005) argued that overconfident CEOs mostly overestimate their projects returns and if they have more internal funds- which are not controlled by capital market or by the rules of corporate governance- then they invest them in new project irrespective of how risky that project may be. If they have no internal funds sufficient for the investment, they issue new equity because overconfident perception leads them to believe that stocks are undervalued by the market. Another study revealed that managerial overconfidence has a positive impact on investment decision. Financial constraints help to enhance managerial biases that ultimately affected the decision making about choosing debt financing or equity financing. They overestimated their returns and underestimated risk (Fischhoff (1994)). Bukalska et al (2020) found that managerial overconfidence increases investment cash flow sensitivity. However, at the same time, companies managed by overconfident managers present higher potential to obtain external funds as they present lower financial constraints. It seems that the financial standing of the companies managed by overconfident managers (lower financial constraints) justifies using debt financing, but overconfident managers intentionally refrain from doing so; instead, they attempt to depend upon internal funds (higher investment-cash flow sensitivity).

Linghong et al (2011) found that overconfident managers tend to overestimate the cashflows and they are more sensitive towards the cash flows from financing activities. Their research also revealed a significant positive association between overconfidence and level of investment. Lin et al (2005) investigated 500 CEOs and their results revealed that CEO overconfidence have increased the sensitivity of the cash flows of those corporations that invested in equity dependent companies. In common, CEOs overestimated the returns of a project, which caused them to face crisis and put a stop in investment.Rzeszutek et al (2021) concluded that overconfident manger has not only a destabilizing effect on the corporation but also on the economy. Dinh Nguyen et al (2021) study also recommends that enterprises with long-term strategies need to control overconfident CEOs decisions.

Fairchild (2009) agreed on the positive relationship between overconfidence and debt financing in running a business, Moreover, he also explained that overconfidence decreased the debt usage when a firm opted for a new project. Therefore, overconfident managers would go for the low level of debt for new project investments because they believed that a new project would increase firm value. Another study has been tested on the behavioural characteristics and financing decision. Researchers of this study revealed that there is a signif-

Business Review: (2021) 16(2):77-95 
icant impact of managerial overconfidence and financing decision (Shahid et al 2021). Various researches in the field of managerial biases have proved that the top management has a greater impact on the decision making of firms and their financial performances. Overconfident managers take decisions that are highly risky because they perceive risk low associated with financing (Crossland and Hambrick 2011). Hackbarth (2008) illustrated in his research work that overconfident managers often issue new debts to finance and choose a high level. He deduced that an optimistic society is also ready to go for high debt and more spendings. From these past results, it is shown that there is a significant effect of CEO overconfidence bias on corporate financing decision.

Hambrick and Cannella Jr (2004) have given implications about overconfident managers while taking decisions. They summarized in three points as follows; first, managers would like to invest more; second, when they invest more they issue more debts and thirdly, they face high default risk in return. They have concluded that the biased managers use high debt financing as compared to rational managers. Adams et al (2005) have taken interviews from CFOs, their results revealed that overconfident chief financial officers invest more that ultimately resulted in the use of long-term debt.

\subsection{CEO overconfidence, risk perception and Capital financing decision}

Risk perception of decision makers affects the quality of the decision. Sitkin and Pablo (1992) have defined risk perception as the investor's judgment of the risk involved in a situation. Previous studies have illustrated that the level of risk involved in a situation affects the investors perception and ultimately his decisions. Perception involves a persons mind and how it interprets the outside environment when a stimulus has been captured from the outside world (Fischhoff 1994). It is a source of communication which makes an investor avoid or take risks on the basis of his understanding of psychological factors (Rana et al., 2011). The different level of risk perception leads the investor to think differently. In the past, many researches have been carried out, which stated that decision making of investors is affected by the person's attitude toward the risk that how an investor perceive risk (Chen et al 2011).

According to Barrett et al (2013) the degree of risk which is linked to a specific behaviour depends on the results of the harmful effects. Perceived risk comprises of the evaluation of the probability and the consequences of a harmful happening. According to him, there are three types of perceived risk. One is the perceived likelihood, which looks into the probability of getting harmed in case of a hazard. Second is the perceived severity which looks at the extent to which harm happened and the last one is the perceived susceptibility, which looks into the individual susceptibility towards a hazard. This behaviour continues from the evolution and in this day, managers face decision-making arenas due to different opportunities and experiences in the emerging business world. They take a decision on the basis of risk analysis; analysing risk mean to identify whether the risk associated with new opportunity is of low level or high (Riaz and Hunjra 2015; Epstein 1994). 
Impact of CEO overconfidence on corporate financing decision...

The standard financial theory assumed that investors behave rationally and perceive that they have unchanged risk preference while taking investment decisions. But with more research in this field, it has been realized that individual behaviour in real life doesnt depend on the assumption that they act rationally. Their behaviour is affected by the cognitive biases and external behaviour that results in different conditions of risk preferences (Wen et al 2014). Past research on risky decision-making has focused on individual risk-taking behaviour in an organizational context especially in managerial decision making (Hamid et al 2013). In prior researches, the impact of managerial overconfidence on risktaking and firm performance has been examined in the non-financial sector. Results revealed that there is a positive relationship between CEO overconfidence and risk-taking and explained that companies must focus on the overconfidence of their managers so that they could balance the risk-taking behavior of managers(Campbell et al 2011; Hirshleifer et al 2012).

Han et al (2015) found that CEO overconfidence has a negative effect on insurer risk-taking. This is also revealed by their research work, which states that according to the change in regulatory and economic environment, CEOs change their risk-taking behaviour. CEO overconfidence was positively related to firm performance, which means that overconfident managers lead to the high stock returns, greater profitability and lower risk to the shareholders. Ullah et al (2017) argued that managers make long-term decisions. Some managers take rational decisions and most of them take an irrational decision by being overconfident. Their results revealed that both managers probability of success is quite different. Papadakis et al (1998) said that for long-term decision making, top management must have to consider the internal and external environment of the organization.

According to Butt et al (2015), the biased managers underestimate the uncertainties in an environment which will lower the risk preference. They think that there is a little risk associated with the project and go for the new venture. Their research shows that this is because of the cognitive biases that compel individuals to act differently in the same risk-taking situation. When they are dealing with borrowing and investment decisions, they are more concerned about their reputation-compelling managers to go for conservative decision-making strategy. If the managers are more confident, then they will go for the high level of idiosyncratic risk (Kraus and Litzenberger 1973). Jensen and Meckling (1976) stated that CEO foreseeing characteristics were the most important factor for strategy makings. Managers of levered firms usually select those investments that are highly risky.

Leverage constraints lead to the selection of risky assets in their portfolio and show that the use of high leverage results in the poor performance of the firm. It means risk and leverage has a direct relationship (Pedersen and Lasse 2011). Psychological findings clearly show that overconfidence biases resulted in underestimating risk and focus on their own abilities. They are more confident about their decision making on the basis of their perceptions and precision of their knowledge. In such a situation, people mostly go for high risk and act against the standard decision-making theory. In such situations, managers will be open to high risk and high probability of loss. Overconfident managers over-

Business Review: (2021) 16(2):77-95 
estimate their knowledge and underestimate the financial distress cost (Tomak 2013). A recent paper of Bernile et al (2017) also revealed that risk play vital role in decision making and they tested the impact of CEO attitude towards risk and on the policies they influence while taking a decision. The result of their study revealed that CEOs who experienced extreme fatal disasters always take a low risk approach and are more conscious.

Based upon the above studies, it has been observed that there is lack of exploration in case of emerging economies like Pakistan. These economies have different economic conditions due to difference in demographics, organizational culture, industry level competition and regulatory framework as compared to developed countries. Market dynamics of these countries like interest rate, flotation costs of debt, cash flows, governance mechanism and volatility of income is different. Therefore, there is a need to study the behaviour of managers and see if their personal biases have any impact on firm level decisions or not.

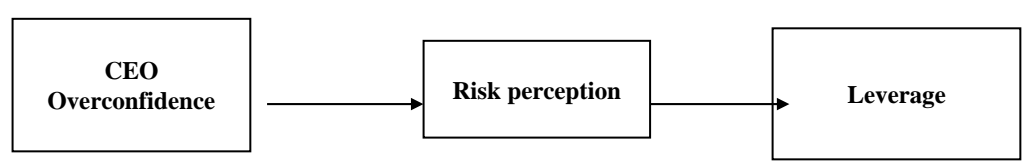

Fig. 1: Theoretical Framework

\subsubsection{Research Hypotheses:}

On the basis of above discussion current study has proposed the following hypotheses.

H1. CEO overconfidence has a significant positive impact on Leverage.

$\mathrm{H} 2$ : There is a significant negative relationship between overconfidence of CEO and CEO risk perception.

H3: There is a significant negative relationship between risk perception and Leverage.

H4: CEO risk perception negatively mediates the relationship between overconfidence and Leverage.

\section{Methodology}

This research work is causal and primary data has been used to test the results of this study. Among all the private limited and public limited non-financial companies in Pakistan, the researcher has chosen 200 companies as a sample. $35 \%$ of the data has been collected from public listed companies and the remaining $65 \%$ has been collected from manufacturing companies that are privately limited. Data has been collected through convenient sampling technique because it is quite difficult to collect the data from executives. E-Questionnaire has been 
Impact of CEO overconfidence on corporate financing decision...

distributed to collect the required data and LinkedIn and other mailing sources have been used to collect information from the executives. The questionnaire used in this study consists of closed-ended questions. Closed-ended questions are easier to analyse once the data is collected compared to data gathered from open-ended questions. Closed-ended data can be easily coded and the respondent does not have as much freedom while answering a specific question.

Rajan and Zingales (1995) present and analysed in their study five different types of leverage measure and this article used one of the classical measure of leverage as debt to total assets in this study. The dependent variable measure is a total debt to total asset ratio and has been measured by adapting Persson and Dahlström (2010) scale. To find the level of overconfidence of CEO while taking financing decisions, Wood and Zaichkowsky (2004) and Allgood and Walstad (2016) scale has been used which is a 5-point Likert scale with nine items. To measure risk perception, Kramer (2016) scale has been used comprising of six items. To test the control variables, demographics of CEO i.e. education, gender, and age are used.

$$
\begin{gathered}
L E V E_{i}=\alpha_{0}+\alpha_{1} O V C O N D_{i}+e_{i} \\
L E V E_{i}=\alpha_{0}+\alpha_{1} O V C O N D_{i}+\alpha_{2} R P_{i}+e_{i}
\end{gathered}
$$

Here:

$L E V E_{i}=$ leverage of the firm i;

$O V C O N F_{i}=$ overconfidence of CEO of the firm i;

$R P_{i}=$ overconfidence of CEO of the firm $\mathrm{i}$;

$e_{i}=$ error term

Here the mediation is done by using the Baron and Kenny four-step approach. In order to examine the mediating role of risk perception on the relationship of overconfidence measure and leverage, the researcher has added $R P_{i}$ in Model 2 that is.

\section{Results and discussion}

Table 1 reports the descriptive statistics and correlation among the variables. Of the 280 distributed e-questionnaires researchers has received back only 200. So our response rate from CEOs is $71.4 \%$. In this research, the contribution of male CEOs is $100 \%$ and none of the women has participated, which can be seen in the frequency table. One of the reasons behind this is that in Pakistani culture, males dominate in work environment, resulting in a smaller proportion of women CEOs. This sample comprises of $4.5 \%$ of the people within the age group of $21-30,49.5 \%$ of people lie within the age group of $31-40$ and $46 \%$ having age group of $40 \&$ above. Education of $23 \%$ of CEOs has graduation and $77 \%$ post graduated. $64 \%$ have a management degree and $36 \%$ dont have any management degree. To control the variables used as demographics, researchers have done 
one-way ANOVA and found that the results of all the demographic variables are insignificant. Therefore, in this research, there is no need to control the demographic variables. The mean value of leverage 1.8 shows that on average, most of the companies perceive to use less amount of debt. Overconfidence of $\mathrm{CEO}$ and risk perception lie on the higher side on average.

Table 1: Summary Descriptive Statistics and Correlation

\begin{tabular}{|c|c|c|c|c|c|c|}
\hline & Percent & Mean & S.D & 5 & 6 & 7 \\
\hline Gender & & 1 & 0 & & & \\
\hline Male & $100 \%$ & & & & & \\
\hline Female & $0 \%$ & & & & & \\
\hline Age & & 3.415 & 0.5783 & & & \\
\hline $21-30$ & $4.50 \%$ & & & & & \\
\hline $31-40$ & $49.50 \%$ & & & & & \\
\hline $40 \&$ above & $46.00 \%$ & & & & & \\
\hline Education & & 1.77 & 0.4218 & & & \\
\hline Graduate & $23 \%$ & & & & & \\
\hline Post Graduate & $77 \%$ & & & & & \\
\hline $\begin{array}{l}\text { Management de- } \\
\text { gree }\end{array}$ & & 1.42 & 0.8931 & & & \\
\hline Yes & $64 \%$ & & & & & \\
\hline No & $36 \%$ & & & & & \\
\hline Overconfidence & & 4.1287 & 0.557 & -0.76 & & \\
\hline Risk Preference & & 4.0975 & 0.7459 & $.012^{*}$ & -0.64 & \\
\hline Leverage & & 1.835 & 0.6222 & $.000^{* *}$ & 0.32 & -0.86 \\
\hline
\end{tabular}

*. Correlation is significant at the 0.05 level (2-tailed)

**. Correlation is significant at the 0.01 level (2-tailed)

Table 1 also reports the correlation among the key variables that are dependent, independent and mediator of this research model. That is a significant correlation between risk perception and overconfidence at a $5 \%$ significance level. Leverage and overconfidence have a significant relationship with each other on a $1 \%$ significance level. Correlation between leverage and risk preference is insignificant. In the above table, diagonally mentioned results in brackets are reliability analysis of the factors of each variable. Cronbachs alpha measures the reliability that questions of the scale used are using to measure the underline variable qualities. It measures the consistency of the tested items. According to Sekaran and Bougie (2016) the value of alpha must be greater than .65 and in other references such as Nunnally (1994), it must be greater than .70. In this research, all the variables items have the reliability of more than .65 .

The ANOVA results show an insignificant result, which means that demographic variables have no impact on the relationship between the independent and dependent variable. Therefore, we can say that demographics in this research are not controlled.

A linear regression has been done to find the relationship between independent variable, overconfidence, and dependent variable, leverage. Regression analysis for Hypothesis1 shows that overconfidence has a significant positive impact on leverage. The results are consistent with the past research work. Equity 
Impact of CEO overconfidence on corporate financing decision...

Table 2: Regression Test

\begin{tabular}{lrrrr}
\hline & R2 & R2 & \multicolumn{2}{c}{ Sig. } \\
\hline $\begin{array}{l}\text { Overconfidence } \\
\text { (Constant) }\end{array}$ & -1.333 & & & \\
$\begin{array}{l}\text { Overconfidence } \\
\text { Overconfidence }\end{array}$ & 0.767 & 0.687 & 0.472 & 0 \\
$\begin{array}{l}\text { \& Risk prefer- } \\
\text { ence (mediator) }\end{array}$ & & & & \\
$\begin{array}{l}\text { Constant) } \\
\text { Risk preference }\end{array}$ & -1.555 & & & \\
$\begin{array}{l}\text { Risk preference } \\
\text { \& Leverage }\end{array}$ & -0.044 & 0.474 & 0.469 & 0 \\
$\begin{array}{l}\text { Constant) } \\
\text { Risk preference }\end{array}$ & 2.077 & & & \\
\hline Depend Variab: & -0.059 & 0.005 & & 0 \\
\hline
\end{tabular}

Dependent Variable: Leverage

Predictor 1: constant, Overconfidence (independent variable)

Predictor 2: constant, Overconfidence (independent variable), risk preference (mediator)

Predictor 3: constant, Risk preference (mediator), Leverage

financing is perceived as excessively costly as compared to internal finance by overconfident CEOs in prior researches. Past research studies have also found strong evidence through collected data that CEOs prefer to invest or finance through debt and are less likely to issue equity. These results are consistent with the results of Wang et al (2013); Abor (2007); Hambrick and Cannella Jr (2004). As upper echelon theory suggests that the CEOs behavioural characteristics are best in assessing their decision such as financing decisions.

According to the work of Eldomiaty (2007) developing countries have different issues as compared to developed countries due to which their results vary accordingly. As in Pakistan, there is a high risk associated with investment due to political instability, frequent foreign currency fluctuation, growing stage capital market and quite high business risk. Investment rate in Pakistan is also low due to some of the other factors described by Hussain (2006)). These are infrastructure, law and order, lack of skilled worker and bureaucratic issues. Due to these issues, overconfident managers go for debt financing and ignore the equity financing. This research has been done on Pakistani companies and due to the weak economic condition and unstable macroeconomic factors, the decision making of a corporation is affecting while choosing the capital structure.

In the next step, the mediation effect of the model has been checked. This mediation effect is analysed through the Baron and Kenny approach of four-step mediation. The researcher has not moved to the fourth step of meditation suggested by Baron and Kenny because if any of the above-mentioned single steps will be insignificant, the combined effect of mediation will not be checked. Table 2 shows that there is a significant negative relationship between CEO overconfidence and risk perception, which is also the second hypothesis of this research. These results are consistent with the results of Butt et al (2015). According to them, the biased managers underestimate the uncertainties in an environment which lowers the risk perception. They think that there is a little risk associated with the project and go for the new venture. Han et al (2015) research work also 
revealed that according to the change in regulatory and economic environment, CEOs change their risk-taking behaviour.

According to one of the analysts, Nabi (2016), Pakistan is heading toward serious debt problem and debt is becoming a threatening situation for the economy and also for the organizations here. He argued that besides he serious condition of debt inside the country, top managers have ignored all this and have preferred to go for debt financing in their companys capital structure. Theoretically, it has been said that according to prospect theory, people take a decision on the basis of perceived gain and losses. Same results are predicted by prospect theory, that is negative and positive perceptions of a person are affected by overconfidence biases.

Table 2 shows that there is an insignificant relationship between risk perception and leverage i.e., hypothesis 3. These results are consistent with the results of Butt et al (2015) and Wang et al (2013). According to their results, risk perception does not have any significant relation with leverage. As the risk perception is affected by some of the macro-level factors such as social and cultural safety factors. Because managers are not thinking about the risk tolerance, they only take a decision on the basis of other factors associated with selecting perfect capital structure (Inouye 2014).

\section{Conclusion}

The purpose of this paper is to investigate the impact of Chief Executive Officers overconfidence on corporate financing decision with the mediating role of risk perception. This study indicates that overconfidence biases affect the risk perception and ultimately financing decision of top management of an organization. The research design is causal and primary data has been used to test the proposed relationship. Among all the companies listed on Pakistan Stock Exchange, researchers have selected top executives of 200 companies as a sample. E-Questionnaire has been used to collect the required data through LinkedIn and other mailing sources. Baron and Kennys four-step mediation has been used to test the mediation effect of risk perception. Results of this study conclude that there is a significant positive relationship between overconfidence of CEO and leverage. These results are in aligned with the work of Yang and Kim (2020) who claim that overconfident mangers adjust even the negative cash flows of the investments thus resulting in positive outcomes. There is a significant negative relationship between CEO overconfidence and risk perception. However, there is an insignificant result for the mediating role of risk perception between CEO overconfidence and leverage.

Findings of this study provide policymakers with a clear picture about the effect of managerial overconfidence on corporate financing decision and how overconfident CEOs perceive risk. Using our results about risk perception, perceiving risk by the overconfident manager is an important factor to be considered as this will be helpful for top management to take corporate financing decision. Findings of this research provide insight into the impact of psychological factors 
on the corporate financing decision of top management through the mediating role of risk perception in the Pakistani context.

This study has several shortcomings regarding the sample size, time, variables etc. This research is conducted with a small sample size due to lack of time and data is collected from CEOs by calling them and connecting through social media. To make these research findings more generalized, future research should be conducted with a larger sample size. Secondly, many of the other factors like past hazard experience of CEO or CEO compensation can also be used as in the model. Thirdly, future research may also be conducted by using the CEO personality traits that comprise of psychological factors other than those used in this research. Business risk is also one of the factors that are affected by managerial biasesmaking it a suitable variable for future research. There is still a lack of research on the decision making in the context of investing in the securities market or investing in debt. As most of the data has been collected from the private sector, it is quite difficult to collect information regarding the profitability and size of the firm. These variables may also be used as an independent variable for further research.

\section{References}

Abor J (2007) Corporate governance and financing decisions of ghanaian listed firms

Adams RB, Almeida H, Ferreira D (2005) Powerful ceos and their impact on corporate performance. The Review of Financial Studies 18(4):1403-1432

Allgood S, Walstad WB (2016) The effects of perceived and actual financial literacy on financial behaviors. Economic inquiry 54(1):675-697

Baron RM, Kenny DA (1986) The moderator-mediator variable distinction in social psychological research: Conceptual, strategic, and statistical considerations. Journal of personality and social psychology 51(6):1173

Barrett EM, Darker CD, Hussey J (2013) Promotion of physical activity in primary care: knowledge and practice of general practitioners and physiotherapists. Journal of Public Health 21(1):63-69

Barros LABdC, Di Miceli da Silveira A (2007) Overconfidence, managerial optimism and the determinants of capital structure. Available at SSRN 953273

Bekaert G, Harvey CR (2002) Research in emerging markets finance: looking to the future. Emerging markets review 3(4):429-448

Ben-David I, Graham JR, Harvey CR (2013) Managerial miscalibration. The Quarterly journal of economics 128(4):1547-1584

Bernile G, Bhagwat V, Rau PR (2017) What doesn't kill you will only make you more riskloving: Early-life disasters and ceo behavior. The Journal of Finance 72(1):167-206

Boubaker A, Mezhoud M (2011) Impact of managerial ownership on operational performance of ipo firms: French context. International Journal of Management Science and Engineering Management 6(3):191-197

Brick IE, Palmon O, Wald JK (2006) Ceo compensation, director compensation, and firm performance: Evidence of cronyism? Journal of Corporate Finance 12(3):403-423

Bukalska E, et al (2020) Are companies managed by overconfident ceo financially constraint? investment-cash flow sensitivity approach. Equilibrium Quarterly Journal of Economics and Economic Policy 15(1):107-131

Butt M, Jamil N, Nawaz R (2015) The mediating role of risk perception among cognitive biases towards decision to start a new venture. International letters of social and humanistic sciences 54:88-95

Campbell TC, Gallmeyer M, Johnson SA, Rutherford J, Stanley BW (2011) Ceo optimism and forced turnover. Journal of Financial Economics 101(3):695-712

Business Review: (2021) 16(2):77-95 
Chen S, Sun Z, Tang S, Wu D (2011) Government intervention and investment efficiency: Evidence from china. Journal of Corporate Finance 17(2):259-271

Crossland C, Hambrick DC (2011) Differences in managerial discretion across countries: how nation-level institutions affect the degree to which ceos matter. Strategic Management Journal 32(8):797-819

Dinh Nguyen D, To TH, Nguyen DV, Phuong Do H (2021) Managerial overconfidence and dividend policy in vietnamese enterprises. Cogent Economics \& Finance 9(1):1885,195

Eldomiaty TI (2007) Determinants of corporate capital structure: evidence from an emerging economy. International Journal of Commerce and Management

Epstein S (1994) Integration of the cognitive and the psychodynamic unconscious. American psychologist 49(8):709

Fairchild R (2009) Managerial overconfidence, moral hazard problems, and excessive life-cycle debt sensitivity. Investment Management and Financial Innovations (6, Iss. 3):35-42

Fischhoff B (1994) Acceptable risk: A conceptual proposal. Risk 5:1

Gigerenzer G, Hoffrage U, Kleinbölting H (1991) Probabilistic mental models: a brunswikian theory of confidence. Psychological review 98(4):506

Hackbarth D (2008) Managerial traits and capital structure decisions. Journal of financial and quantitative analysis 43(4):843-881

Hambrick DC, Cannella Jr AA (2004) Ceos who have coos: Contingency analysis of an unexplored structural form. Strategic Management Journal 25(10):959-979

Hambrick DC, Mason PA (1984) Upper echelons: The organization as a reflection of its top managers. Academy of management review 9(2):193-206

Hamid FS, Rangel GJ, Taib FM, Thurasamy R (2013) The relationship between risk propensity, risk perception and risk-taking behaviour in an emerging market. International Journal of Banking and Finance 10(1):134-146

Han S, Lai G, Ho C (2015) Ceo confidence or overconfidence? the impact of ceo overconfidence on risk taking and firm performance in the us property-liability insurance companies. In: The World Risk and Insurance Economics Congress, pp 1-55

Heaton JB (2005) Managerial optimism and corporate finance. In: Advances in Behavioral Finance, Volume II, Princeton University Press, pp 667-684

Hilary G, Hsu C (2011) Endogenous overconfidence in managerial forecasts. Journal of Accounting and Economics 51(3):300-313

Hirshleifer D, Low A, Teoh SH (2012) Are overconfident ceos better innovators? The journal of finance $67(4): 1457-1498$

Hussain I (2006) Pakistan's investment scenario and capital markets

Inouye J (2014) Risk perception: Theories, strategies, and next steps. Itasca, IL: Campbell Institute National Safety Council

Jensen MC, Meckling WH (1976) Theory of the firm: Managerial behavior, agency costs and ownership structure. Journal of financial economics 3(4):305-360

Kahneman D, Riepe MW (1998) Aspects of investor psychology. Journal of portfolio management 24(4):52-+

Kahneman D, Tversky A (2013) Prospect theory: An analysis of decision under risk. In: Handbook of the fundamentals of financial decision making: Part I, World Scientific, pp 99-127

Koralalage WBY (2016) Cfos views on corporate financing decisions: Evidence from emerging market of sri lanka. Qualitative Research in Financial Markets

Kramer MM (2016) Financial literacy, confidence and financial advice seeking. Journal of Economic Behavior \& Organization 131:198-217

Kraus A, Litzenberger RH (1973) A state-preference model of optimal financial leverage. The journal of finance 28(4):911-922

Kruger J, Dunning D (1999) Unskilled and unaware of it: how difficulties in recognizing one's own incompetence lead to inflated self-assessments. Journal of personality and social psychology $77(6): 1121$

Liang T, Mo X (2016) Research on the relationship between managerial overconfidence and corporate $\mathrm{r} \& \mathrm{~d}$ investment in the context of financing constraints. Open Journal of Business and Management 5(1):22-33

Lin Yh, Hu Sy, Chen Ms (2005) Managerial optimism and corporate investment: Some empirical evidence from taiwan. Pacific-Basin Finance Journal 13(5):523-546 
Impact of CEO overconfidence on corporate financing decision...

Linghong X, Shancun L, Wanhua Q (2011) Impact of learning managers' over-confidence in serial m\&a performancesdata from china's listed companies. Management Review p 07

Miller EM (1977) Risk, uncertainty, and divergence of opinion. The Journal of finance $32(4): 1151-1168$

Myers SC, Majluf NS (1984) Corporate financing and investment decisions when firms have information that investors do not have. Journal of financial economics 13(2):187-221

Nabi I (2016) Is pakistan heading towards a serious debt problem. Perspective, December pp $16-2016$

Nunnally JC (1994) Psychometric theory 3E. Tata McGraw-hill education

Papadakis VM, Lioukas S, Chambers D (1998) Strategic decision-making processes: the role of management and context. Strategic management journal 19(2):115-147

Pedersen AF, Lasse H (2011) Betting against beta

Persson A, Dahlström N (2010) Capital structure decisions: A case study on high growth smes listed on ngm equity in sweden

Rajan RG, Zingales L (1995) What do we know about capital structure? some evidence from international data. The journal of Finance 50(5):1421-1460

Riaz L, Hunjra AI (2015) Relationship between psychological factors and investment decision making: The mediating role of risk perception. Pakistan Journal of Commerce and Social Sciences 9(3):968-981

Rzeszutek M, Godin A, Szyszka A, Augier S (2021) Managerial overconfidence in capital structure decisions and its link to aggregate demand: An agent-based model perspective. PloS one 16(8):e255,537

Sekaran U, Bougie R (2016) Research methods for business: A skill building approach. John Wiley \& Sons

Shahid S, Samim BA, Badar M (2021) Influence of demographic and behavioral characteristics on financial decision making while assessing risk and return. Journal of Poverty and Investment

Sitkin SB, Pablo AL (1992) Reconceptualizing the determinants of risk behavior. Academy of management review 17(1):9-38

Ting IWK, Lean HH, Kweh QL, Azizan NA (2016) Managerial overconfidence, government intervention and corporate financing decision. International Journal of Managerial Finance

Tomak S (2013) The impact of overconfidence on capital structure in turkey. International journal of economics and financial issues 3(2):512

Ullah I, Awais M, Jebran K, Abidy M (2017) Overconfidence behavior and managerial decisions: Evidence from pakistan. Research Journal of Finance and Accounting 8:28-35

Wang CY, Chen YF, Yu CW (2013) Managerial optimism and post-financing stock performance in taiwan: A comparison of debt and equity financing. Economics Letters 119(3):332-335

Wei J, Min X, Jiaxing Y (2011) Managerial overconfidence and debt maturity structure of firms: Analysis based on china's listed companies. China Finance Review International

Weinstein ND (1980) Unrealistic optimism about future life events. Journal of personality and social psychology 39(5):806

Wen F, He Z, Chen X (2014) Investors risk preference characteristics and conditional skewness. Mathematical Problems in Engineering 2014

Wood R, Zaichkowsky JL (2004) Attitudes and trading behavior of stock market investors: A segmentation approach. The Journal of Behavioral Finance 5(3):170-179

Yang D, Kim H (2020) Managerial overconfidence and manipulation of operating cash flow: Evidence from korea. Finance Research Letters 32:101,343

\section{Appendix}

\section{Questionnaire}

Faculty of Management Sciences

amnaabid5@gmail.com

Dear Respondent:

Thank you for agreeing to participate in this research survey. I am a student

Business Review: (2021) 16(2):77-95 
of Faculty of Management Sciences Islamic International University Islamabad conducting research on Impact of top executives overconfidence on corporate Financing decision: In reference to mediating role of risk preference and moderating role of government intervention in Pakistani companies. The data will only be accessed by the researcher and all personal data will be kept strictly confidential. Please be as honest and accurate as you can throughout.

$\mathrm{SD}=$ Strongly Disagree, $\mathrm{D}=$ Disagree, $\mathrm{N}=$ Neutral, $\mathrm{A}=$ Agree, $\mathrm{SA}=$ Strongly Agree

Table 3: Add caption

\begin{tabular}{|c|c|c|c|c|c|}
\hline Wood and Zaichkowsky (2004) & SD & $\mathbf{D}$ & $\mathbf{N}$ & A & SA \\
\hline $\begin{array}{l}\text { I am an experienced investor } \\
\text { I feel that on average my invest- } \\
\text { ments } \\
\text { perform better than the stock } \\
\text { market. } \\
\text { When I purchase a winning in- } \\
\text { vestment,I feel that my actions } \\
\text { and knowledge affected the re- } \\
\text { sult. } \\
\text { I expect my investments to per- } \\
\text { form better than the stock mar- } \\
\text { ket. } \\
\text { I feel more confident in my own } \\
\text { investment opinions } \\
\text { over opinions of financial ana- } \\
\text { lysts and advisors. } \\
\text { I feel more confident in my own } \\
\text { investment opinions over opin- } \\
\text { ions of friends and colleagues } \\
\text { I am likely to purchase invest- } \\
\text { ments that have } \\
\text { been recommended by friends } \\
\text { or colleagues } \\
\text { Kramer (2016); Allgood and } \\
\text { Walstad (2016) }\end{array}$ & & & & & \\
\hline
\end{tabular}

How knowledgeable do you consider yourself with respect to nancial matters?

1. Not knowlegable

2. Quite knowledgeable

3. No idea

4. Knowledgeable

5. Very knowledgeable

Financial knowledge varies from person to person. How would you assess your own nancial knowledge?

1. Very low 
2. Low

3. Neutral

4. High

5. Very High

Table 4: Add caption

\begin{tabular}{l}
\hline Risk Preference \\
\hline Kramer $(2016)$ \\
\hline I think it is more im- \\
portant to have safe in- \\
vestments and guaran- \\
teed returns \\
than to take a risk to \\
have a chance to get \\
the highest possible re- \\
turns. \\
I would never consider \\
investments in \\
shares because I nd this \\
too risky. \\
If I think an investment \\
will be protable, \\
I am prepared to bor- \\
row money to make this \\
investment. \\
I want to be certain \\
that my investments are \\
safe. \\
I get more and more \\
convinced that I should \\
take greater nancial \\
risks to improve my \\
nancial position. \\
I am prepared to take \\
the risk to lose money, \\
when there is also a \\
chance to gain money. \\
\hline
\end{tabular}

Over the last three years, how would you consider your firms growth compared to other companies in your industry?

1. Way below average

2. Below average

3.Average

4. Above average

5. Way above average

Following questions refer to companys capital structure. Capital structure refers to the mix of debt and equity in a company.

How actively does your company decide upon the mix of debt and equity when

Business Review: (2021) 16(2):77-95 
financing overall investments?

1. Not active at all

2. Not active, external part such as bank does it for our company

3. Active to a certain degree, external part such as bank cooperates with our representative

4. Active, external part gives advices on our companys own decisions

5. Active to a great degree, we manage our capital structure on our own

Following questions should be ranked according to your preference where numbers 1 to 5 represent increasing levels of involvement in maintaining an optimal level of debt.

To what extent does your company maintain an optimum debt level?

1. We avoid the use of debt

2. We are indifferent to maintaining a particular level of debt

3.We do actively maintain an optimum debt level

With regard to capital structure decisions, how important is financial flexibility?

1. Not important at all

2.Important

3. Very important

With regards to capital structure decisions, how important is the tax advantage of debt interest deductibility?

1. Not important at all

2.Important

3. Very important

With regards to capital structure decisions, how important is ownership control?

1. Not important at all

2.Important

3. Very important

Given equal access to external debt and external equity when financing overall investments in your company external debt is preferred over external equity.

1. Strongly disagree, equity is preferred over debt

2. Disagree

3. Debt and equity are equally preferred

4. Agree

5. Strongly agree, debt is preferred over equity

If available, when financing overall investments internally generated funds are preferred over external funds.

1. Strongly disagree, equity is preferred over debt

2. Disagree 
3. 3. Internally and externally generated funds are equally preferred

4. Agree

5. Strongly agree

\section{Personal Information}

Company Name:

Email address (if any):

Gender:

1. Male

2. Female

Age:

1. less than 20

2. 21 to 30

3.31 to 40

4.41 and above

Degree:

1. Graduate

2. Postgraduate

Management Degree:

1.Yes

2.No 